MARIA JANAS

Uniwersytet Pedagogiczny w Krakowie, Polska - Pedagogical University of Krakow, Poland

\title{
Postawy wobec przedsiębiorczości uczniów w młodszym wieku szkolnym
}

\section{Attitudes towards Entrepreneurship Exhibited by Younger School-Age Students}

Streszczenie: $\mathrm{W}$ artykule podjęta została tematyka rozwijania kompetencji przedsiębiorczych u uczniów w młodszym wieku szkolnym. Termin „przedsiębiorczość” wyjaśniono w kontekście podstawowych dokumentów regulujących kwestię rozwijania kompetencji kluczowych na I etapie kształcenia, a także przykładowych dobrych praktyk i strategii, służących rozwijaniu postawy przedsiębiorczej. Celem przeprowadzonych badań było uzyskanie informacji o tym: jak uczniowie klas trzecich definiują terminy: „przedsiębiorczość”, „przedsiębiorca”, czy uważają się za osoby przedsiębiorcze i czy dostrzegają w szkole inicjatywy podejmowane na rzecz stymulowania tej ważnej dla skutecznej edukacji kompetencji. W badaniach wykorzystano metodę sondażu diagnostycznego i technikę ankiety. Uzyskane wyniki nie służą formułowaniu uogólnień czy stawianiu tez, lecz sygnalizują, że badani uczniowie rozumieją terminy: „przedsiębiorczość” i „przedsiębiorca” w sposób potoczny, który odbiega od definicji literaturowych. Badani respondenci nie posiadają wystarczającej wiedzy o cechach charakteryzujących osobę przedsiębiorczą, a podejmowane w szkołach działania na rzecz rozwijania postawy przedsiębiorczej są realizowane w niewystarczającym zakresie.

Abstract: The article discusses the topic of developing entrepreneurial competences in younger school age students. The term entrepreneurship is explained in the context of basic documents regulating the issue of developing key competences at the first stage of education, as well as examples of good practices and strategies to develop an entrepreneurial attitude. The aim of the research was to obtain information on how third-grade students define the concepts of entrepreneurship and entrepreneur, do they consider themselves entrepreneurial, and do they see in the initiatives organised at school initiatives to stimulate this important competence for effective education. The research used diagnostic survey method and survey technique. The obtained results are not used to formulate generalisations or to put forward theses, but to signal that the surveyed students present a colloquial understanding of the terms: entrepreneurship, entrepreneur, which deviate from their academic definitions. The surveyed respondents do not have sufficient knowledge about the characteristics of an entrepreneurial person, and the actions taken at school to develop the entrepreneurial attitude are insufficiently implemented. 
Słowa kluczowe: edukacja przedsiębiorcza; edukacja wczesnoszkolna; kompetencje przedsiębiorcze; postawa przedsiębiorcza; przedsiębiorczość; strategie rozwijania przedsiębiorczości

Keywords: early school education; entrepreneurial attitude; entrepreneurial competences; entrepreneurial education; entrepreneurship; entrepreneurship development strategies

Otrzymano: 1 kwietnia 2020

Received: 1 April 2020

Zaakceptowano: 30 lipca 2020

Accepted: 30 July 2020

\section{Sugerowana cytacja/Suggested citation:}

Janas, M. (2020). Postawy wobec przedsiębiorczości uczniów w młodszym wieku szkolnym. Przedsiębiorczość - Edukacja [Entrepreneurship - Education], 16(2), 48-60. doi: $10.24917 / 20833296.162 .4$

\section{Wstęp}

Priorytetem toczących się dyskusji i debat w obszarze edukacji w ostatnim czasie staje się zagadnienie skuteczności oddziaływań szkoły i jej powiązań z kompetencjami kluczowymi, które zgodnie z wytycznymi Komisji Europejskiej powinny być rozwijane na każdym etapie kształcenia. Zainteresowanie to wynika z nieustających i gwałtownie postępujących przeobrażeń widocznych we wszystkich dziedzinach życia. Tempo procesów cywilizacyjnych i globalizacyjnych oraz eksplozja technologii cyfrowej determinują nie tylko konieczność przejścia od zachowań replikacyjnych do zachowań innowacyjnych, lecz także konieczność zmian w sposobie myślenia o edukacji i promowania w niej postaw przedsiębiorczych. Szczególnie przedstawiciele sektora edukacji - zarówno badacze pedeutolodzy, jak i pedagodzy praktycy - powinni stale głębiej zastanawiać się nad kształtem edukacji, wyznaczanymi w niej wciąż nowymi celami i priorytetami, czyli aspektami, od których w dużej mierze zależy przyszłość i funkcjonowanie uczniów.

Życie w czasach płynnej rzeczywistości wymaga zintensyfikowania działań i strategii w zakresie edukacji przedsiębiorczej, która wydaje się już nie alternatywą czy propozycją, lecz koniecznością, a zarazem trudnym zadaniem dla współczesnego szkolnictwa, odpowiedzialnego zarówno za wytyczanie celów, jak i za wdrażanie mechanizmów skutecznie przygotowujących uczniów do umiejętnego adaptowania się w świecie ciągłych zmian.

W celu zweryfikowania, czy zapisy obecne w dokumentach akcentujących znaczące miejsce przedsiębiorczości na etapie edukacji wczesnoszkolnej są faktycznie implementowane przez nauczycieli do praktyki szkolnej, podjęto próbę sprawdzenia, czy współcześni uczniowie klas trzecich w wybranych losowo podtarnowskich szkołach podstawowych posiadają wiedzę o przedsiębiorczości, czy potrafią zdefiniować termin "przedsiębiorczość" i wskazać cechy osoby przedsiębiorczej, czy dostrzegają u siebie cechy typowe dla postawy przedsiębiorczej, a także, czy mają możliwość podejmowania w swoim szkolnym otoczeniu przedsiębiorczych inicjatywy. Do badań przeprowadzonych w okresie grudzień 2019 - styczeń 2020 wykorzystano metodę sondażu diagnostycznego. 
Uwarunkowania prawne kształtowania kompetencji przedsiębiorczych w edukacji wczesnoszkolnej

Problematyka braku przystawalności i użyteczności nabywanych w szkole kompetencji do aktualnych potrzeb człowieka jest podnoszona przez coraz szersze grono ekspertów. Efektem tych dyskusji stają się słusznie dokonywane zmiany w dokumentach - zarówno europejskich, jak i wewnątrzkrajowych - regulujących kwestię wyposażania uczniów w kompetencje przedsiębiorcze. Aktualnie urzędnicy Unii Europejskiej (UE) mocno akcentują, że rozwój krajów członkowskich UE ma być zapewniony dzięki przedsiębiorczości i wiążącej się z tym większej liczbie przedsiębiorców, cechujących się przedsiębiorczym nastawieniem (Zalecenie..., 2018) oraz prezentujących przedsiębiorcze postawy (Holmgren, From, 2005).

Mimo że w sformułowanym w 2018 r. przez Parlament Europejski i Radę UE tzw. Zaleceniu $w$ sprawie kompetencji kluczowych w procesie uczenia się przez cate życie, będącym modyfikacją przyjętych wcześniej referencji (Zalecenie..., 2006) definicja kompetencji kluczowych nie uległa dewaluacji i nadal rozumiana jest jako dynamiczna kombinacja wiedzy, umiejętności i postaw, to jednak dokonała się ewolucja w wymaganiach dotyczących poszczególnych kompetencji, w tym kompetencji przedsiębiorczych.

W obowiązującym nowym Zaleceniu... z 2018 r. można wskazać na uproszczoną nazwę kompetencji przedsiębiorczej, która we wcześniejszym dokumencie ujęta była w połączeniu z tzw. inicjatywnością, co w opinii T. Rachwała było zabiegiem mylącym, niefortunnym, gdyż inicjatywność można uznać za cechę, element kompetencji behawioralnych (osobistych) osoby przedsiębiorczej (Rachwał, 2019). W nowej deskrypcji omawianego terminu skoncentrowano się nie tyle na tym, czemu służą kompetencje przedsiębiorcze, ile na tym, na czym się one opierają. Poczynione korekty dotyczą obszerniej ukazanych odwołań do procesów ekonomicznych, umiejętności podejmowania decyzji finansowych oraz skutecznego komunikowania się i negocjowania $\mathrm{z}$ innymi. W większym stopniu zwrócono uwagę na proaktywność jednostki oraz na umiejętność przyjmowania przez nią zasad i postaw etycznych. Podkreślono również, że przedsiębiorczość powinna wiązać się ze świadomością wyzwań, atutów oraz słabych stron jednostki, radzenia sobie z niepewnością, dwuznacznością i ryzykiem, nierozerwalnie związanymi z podejmowaniem decyzji (Rachwał, 2019).

Analizując dokumenty regulujące kwestię rozwijania przedsiębiorczości na etapie edukacji wczesnoszkolnej, można zauważyć, że nastąpiła implementacja zaleceń europejskich do dokumentów obowiązujących obecnie w Polsce, określających cele, treści, metody oraz formy rozwijania tej kompetencji w szkole, z uwzględnieniem wiedzy ekonomicznej, biznesowej, a także postawy przedsiębiorczej.

Podstawowym uregulowaniem prawnym obowiązującym w polskim systemie szkolnictwa jest ustawa Prawo oświatowe (Ustawa z dnia 14 grudnia 2016 Prawo oświatowe...), na podstawie której minister edukacji narodowej ustala kierunki realizacji polityki oświatowej państwa na dany rok szkolny. W bieżącym roku szkolnym na liście wskazanych przez MEN podstawowych kierunków polityki oświatowej państwa znalazła się również przedsiębiorczość jako istotna kompetencja, na którą ciągle istnieje zapotrzebowanie. Również w najnowszej podstawie programowej z 2017 r. można wskazać na obszary, 
w których wyraźnie akcentuje się przedsiębiorczość jako niezbędną w życiu kompetencję. Kształtowanie postaw przedsiębiorczych ujęte zostało głównie w treściach z zakresu edukacji polonistycznej, matematycznej i społecznej (Rozporządzenie...).

Badacze podkreślają, że to nie liczba zapisów europejskich czy wewnątrzkrajowych, dotyczących przedsiębiorczości gwarantuje efektywne kształtowanie kompetencji przedsiębiorczych ucznia, lecz przede wszystkim działania kompetentnego nauczyciela, sprawnie dokonującego implementacji tych wytycznych w praktyce szkolnej (Brzezińska, Schmidt, 2008).

\section{Przedsiębiorczość - wyjaśnienia terminologiczne}

Na podstawie analizy literatury przedmiotu można zauważyć, że pojęcie przedsiębiorczości wiąż dynamicznie ewoluuje i wymaga stałego redefiniowania. Uznając przedsiębiorczość za zjawisko złożone, wielowymiarowe i polisemiczne, cechujące się interdyscyplinarnością oraz wielowątkowością dyskursu, jak zauważa Rachwał, dla celów edukacyjnych konieczne jest przyjęcie spójnego spojrzenia na to zagadnienie (Rachwał, 2019). Celowość doprecyzowania tego pojęcia w kontekście edukacji wczesnoszkolnej wynika z potrzeby dostosowania go do różnych odbiorców i decydentów (autorów podstaw programowych, podręczników, nauczycieli i przede wszystkim uczniów).

Definiowana potocznie "przedsiębiorczość" jest często mylnie kojarzona wyłącznie z działaniami natury ekonomicznej, podczas gdy w rzeczywistości obejmuje ona wiele różnych aktywności, prowadzących do osiągania pozytywnych efektów własnej pracy (Gołębiowski, 2014; Majkut, 2014). Niezależnie od różnych ujęć teoretyczno-metodologicznych w zakresie definiowania przedsiębiorczości można wskazać na szerszą, nie tylko biznesową perspektywę wyjaśniania tego terminu, przez ukazanie cech i sposobu zachowania się osoby przedsiębiorczej zdolnej do: dostrzegania potrzeb, generowania niekonwencjonalnych pomysłów, twórczego rozwiązywania problemów, podejmowania ryzyka i elastycznego działania w dynamicznie zmieniających się warunkach otoczenia oraz innowacyjnej i wyznaczającej sobie ambitne cele, gotowej do wdrażania nowatorskich pomysłów i dostrzegania szans (Brzezińska, Szmidt, 2008). Należy podkreślić, że o przyjmowaniu przez człowieka postawy przedsiębiorczej decydują nie tylko wrodzone predyspozycje, lecz także warunki zewnętrzne (Sadowska, 2016).

Szerszą perspektywę w spojrzeniu na przedsiębiorczość zaproponowała T. Piecuch, której zdaniem pojęcie to można wyjaśnić jako proces, zachowanie lub postawę (Piecuch, 2013). Procesualność przedsiębiorczości wyraża się w aktywności jednostki, w jej działaniu i podejmowaniu przez nią ryzyka. Przez przedsiębiorczość jako zachowanie rozumie się aktywność podmiotu, umożliwiającą mu szybką reakcję na określone warunki otoczenia i zmieniające się okoliczności oraz wykorzystywanie szans, których inni nie dostrzegają. Trzecia wskazana przez autorkę kategoria to tzw. postawa przedsiębiorcza, definiowana jako predyspozycje (poglądy, opinie, odczucia jednostki) niezbędne do ulepszania siebie i poprawiania warunków życia. Tak rozumianą definicję przedsiębiorczości, skierowaną na kształtowanie przedsiębiorczych postaw, można skutecznie wykorzystać w edukacji wczesnoszkolnej ukierunkowanej na rozwijanie zarówno przedsiębiorczości, jak i intencji przedsiębiorczych, które umożliwiają podjęcie konkretnych działań i dostrzeganie możliwości biznesowych (Roudaki, 2009; Uygun, Kasimoglu, 2013). 
W przypadku edukacji wczesnoszkolnej przedsiębiorczość powinna być ujmowana nie tylko przez pryzmat ekonomii, lecz także jako kompetencja życiowa, umożliwiająca sprawne odnajdywanie się w różnych rolach, zakresach oraz sytuacjach życiowych, co nie wyklucza podejmowania działań sprzyjających kształtowaniu umiejętności biznesowych, predysponujących ucznia do efektywnego wejścia w rolę przedsiębiorcy w życiu dorosłym.

To szerokie ujęcie pozwala uznać definicję przedsiębiorczości za kompetencję kluczową, która opiera się na: kreatywności, obejmującej wyobraźnię, myślenie strategiczne i rozwiązywanie problemów, krytycznym myśleniu, podejmowaniu inicjatywy i wdrażaniu innowacji, wytrwałości oraz zdolności do indywidualnego i wspólnego działania, służącego planowaniu projektów (Zalecenie..., 2018) i która wydaje się być najbardziej adekwatna dla omawianego szczebla kształcenia.

\section{Strategie rozwijania przedsiębiorczości uczniów edukacji wczesnoszkolnej - dobre praktyki}

Interdyscyplinarny i integracyjny model edukacji wczesnoszkolnej umożliwia wkomponowywanie zagadnień $\mathrm{z}$ zakresu przedsiębiorczości $\mathrm{w}$ tok planowanych aktywności na różnych zajęciach. Nauczanie przedsiębiorczości powinno być realizowane różnymi metodami zarówno w rzeczywistych, jak i w symulowanych sytuacjach, tworzących okazję do indywidualnego i zespołowego działania często w niekonwencjonalny sposób.

$\mathrm{Na}$ pierwszym etapie edukacyjnym istotne jest stymulowanie aktywnych postaw, rozwijanie poczucia inicjatywności, wytrwałości, odpowiedzialności za siebie i innych, odwagi, przewidywania konsekwencji podjętych decyzji oraz dystansu do popełnianych błędów. W zakres stymulowanej w warunkach szkolnych przedsiębiorczości na pierwszym etapie edukacyjnym powinny wchodzić także takie elementy, jak: gotowość do działania i generowania rozwiązań, elastyczność w zastosowaniu dostępnych środków, a także świadomość zasad etycznych (Andrzejczyk, 2016). Nauczyciel edukacji wczesnoszkolnej powinien premiować zachowania, w których ujawniają się istotne dla przedsiębiorczości cechy charakteru i osobowości, co w przyszłości może zaowocować odpowiedzialnymi zachowaniami przedsiębiorczymi.

Kompetencje przedsiębiorcze dzieci powinny być rozwijane stopniowo z uwzględnieniem ich możliwości percepcyjnych oraz skutecznych metod uczenia się - nauczania, co wyznacza model określany mianem szczebli przedsiębiorczości (Wach, 2013). Zgodnie z tym konstruktem wiedza, umiejętności i kompetencje budowane na niższych poziomach stanowią podwalinę kolejnych, bardziej skomplikowanych, złożonych wiadomości i umiejętności.

W oddziaływaniach edukacyjno-wychowawczych zgodnie z prezentowaną koncepcją można wyróżnić trzy zasadnicze obszary. Pierwszy odnosi się do rozwijania zdolności wykorzystywania dostępnych zasobów, także wiedzy pozaekonomicznej czy pozaprzedsiębiorczej, celem wykształcenia aktywnego stosunku do zdobytych wiadomości i praktycznego ich wykorzystywania. Drugi obszar, wyznaczony przez potrzebę wyrobienia nawyku elastycznego i szybkiego reagowania na zachodzące zmiany, dotyczy przeciwdziałania bierności w relacji z otoczeniem. Trzecia płaszczyzna wymaga od nauczyciela dostrzegania i doceniania nawet najmniejszych przejawów pomysłowości, twórczości i innowacyjności dzieci w celu wspierania ich w dochodzeniu do zamierzonego efektu 
w sposób etyczny i twórczy. Za najbardziej sprzyjający temu wielopłaszczyznowemu oddziaływaniu należy uznać konstruktywistyczno-interakcyjny model organizowania środowiska uczenia się - nauczania (Kapica, 2015), z uwzględnieniem strefy najbliższego rozwoju dziecka. Czasami wystarczy jedynie inspirować uczniów do działania i samodzielnego wykonywania zadań, by z konsumentów sytuacji edukacyjnej stali się aktywnymi jej współtwórcami.

Nauczyciel powinien też umożliwić uczniom: planowanie, organizowanie, realizację i ewaluację atrakcyjnego dla nich przedsięwzięcia, np. przedstawienia teatralnego. Działania uczniów powinny mieć charakter praktycznych subinnowacji, w których dziecko staje się twórcą, odkrywcą i doświadcza osobistego wpływu na uczenie. Przykładem może być projekt „Przedsiębiorcze dzieci”, umożliwiający jego uczestnikom zaplanowanie i wdrożenie pomysłów dotyczących np. aranżacji przestrzeni klasowej. Zadania proponowane uczniom powinny rozwijać umiejętność określania potencjalnych odbiorców produktu, szacowania potrzebnych nakładów, tworzenia reklamy, przewidywania konsekwencji podjętych działań oraz ponoszenia za nie odpowiedzialności.

Szczególne miejsce powinna zajmować przedsiębiorczość społeczna, np. akcje charytatywne, kiermasze na rzecz potrzebujących osób, zwierząt, pomoc rówieśnikom, osobom chorym, starszym, a więc działania o cechach wolontariatu, dzięki którym dzieci uczą się praktykować przedsiębiorczą empatię, a jednocześnie doświadczają autentycznej satysfakcji.

W wachlarzu proaktywnych strategii kształtujących postawy przedsiębiorcze warto wskazać na aktywizujące metody problemowe (metoda projektu, giełda pomysłów, inscenizacje i gry dydaktyczne, burze mózgów, mapy myśli, piramidy priorytetów, kule śnieżne, debaty), umożliwiające uczniom rozwiązywanie problemów drogą poszukiwania, dociekania, eksperymentowania i doświadczania. Posiłkowanie się materiałami ilustracyjnymi, filmowymi i graficznymi może ułatwić uczniom zrozumienie zależności między trudniejszymi pojęciami z zakresu ekonomii (biznesplan, kosztorys, usługi, cennik, reklama). Uczeń powinien mieć szansę wykorzystania zdobytej wiedzy w działaniach praktycznych podejmowanych zarówno indywidualnie, jak i zespołowo, np. w ramach pracy metodą grup eksperckich.

Duże znaczenie mają strategie eksponujące połączone z uczeniem się przez przeżywanie, oddziałujące na emocjonalne zaangażowanie uczniów, wzmacniające ich motywację, pozwalające ryzykować, odwzorowywać dobre praktyki, marzyć i odczuwać satysfakcję z uzyskanego rezultatu. Rozwijanie postawy przedsiębiorczej powinno wiązać się z kształtowaniem umiejętności poszukiwania skutecznych strategii uczenia się, redukujących stres w obliczu trudności i pozwalających ewentualne niepowodzenia traktować nie jako skutek małych zdolności czy możliwości, ale jako efekt zbyt małego wysiłku włożonego w wykonanie zadania.

W kształtowaniu przedsiębiorczych postaw istotne są powiązania między działaniami szkolnymi a realiami życia. Dobrymi praktykami są: opracowanie budżetu domowego, tworzenie reklamy produktów, porównywanie cen, faktyczne robienie zakupów, zapoznawanie uczniów z instytucjami działającymi w ich otoczeniu społecznym (np. bankami, firmami, urzędami i lokalnymi przedsiębiorstwami). Organizowanie spotkań z przedstawicielami różnych profesji, biznesmenami, pozwalające na bezpośredni kontakt z osobami aktywnymi przedsiębiorczo (najlepiej na rynku lokalnym), które odniosły sukces i mogą podzielić się doświadczeniem w tym zakresie, umożliwia uczniom poznanie rynku 
pracy i emocjonalne zaangażowanie się w życie i osiągnięcia lokalnej społeczności. Pozyskiwanie przez uczniów sponsorów do zainwestowania w zgłaszane przez nich pomysły nie tylko stanowi podstawę do zdobycia środków potrzebnych do realizacji projektów, ale również wzmacnia poczucie sprawstwa i zaradności życiowej.

Warto sięgać też po programy popularyzujące edukację finansową bądź ekonomiczną, takie jak projekt „Od grosika do złotówki”", a także do udostępnianych przez banki, np. PKO $\mathrm{BP}^{2}$, materiałów zawierających zagadnienia rzadko eksponowane w treściach podręcznikowych pierwszego etapu edukacji, takie jak ekooszczędzanie i świadome gospodarowanie funduszami.

Priorytetami szkolnych oddziaływań powinny być rozwój dziecięcych zainteresowań i pasji oraz kształtowanie umiejętności uczenia się. Istotne w tym względzie są działania zapoznające uczniów z sektorem nauki i biznesu, np. wyjazdy do jednostek badawczych, uczelni i innowacyjnych firm, uczestnictwo w konferencjach naukowych, dniach otwartych uczelni, specjalistycznych wykładach, festiwalach nauki, projektach i grantach unijnych (np. projekt „Uniwersytet Małego Naukowca: wiedza - ciekawość - pasja”), umożliwiające uczniom zapoznanie się z trendami współczesnej nauki i różnymi ścieżkami kariery zawodowej. Uczniowie działający aktywnie w zespołach badawczych, uczestniczący w tzw. Piknikach Młodych Naukowców, powinni doskonalić umiejętność prezentacji własnych osiągnięć podczas publicznych wystąpień w ramach różnych paneli integracyjno-naukowych i wymieniać doświadczenia, motywując się do aktywnego działania na rzecz swojego środowiska, a tym samym rozwijając kompetencje społeczne i obywatelskie.

\section{Przedsiębiorczość w ujęciu uczniów klasy trzeciej szkoły podstawowej- badania własne}

Celem przeprowadzonych badań empirycznych było uzyskanie informacji o tym, jak uczniowie klas trzecich szkoły podstawowej postrzegają przedsiębiorczość i cechy osoby przedsiębiorczej, a zatem próba ustalenia, jak dzieci w młodszym wieku szkolnym definiują pojęcie przedsiębiorczości. Drugim motywem poczynionych refleksji była chęć ustalenia, czy uczniowie młodszych klas uważają się za osoby przedsiębiorcze i czy dostrzegają w szkole inicjatywy podejmowane w obszarze przedsiębiorczości. Do badań wykorzystano metodę sondażu diagnostycznego, która pozwala badać zjawiska społeczne, opinie czy poglądy określonych zbiorowości, i zastosowano formularz ankiety, składający się z siedmiu pytań, w tym pytań otwartych oraz pytań zamkniętych jednokrotnego i wielokrotnego wyboru.

Badaniami objęto 110 trzecioklasistów uczęszczających w roku szkolnym 2019/2020 do losowo wybranych szkół podstawowych w powiecie tarnowskim (województwo małopolskie). Ankietowani udzielali odpowiedzi pisemnych na zadane w kwestionariuszu pytania w okresie: grudzień 2019 - luty 2020 roku. Do analizy uwzględniono 108 ankiet.

Przeprowadzone badania miały charakter opisowy i diagnostyczny, założono bowiem, że ze względu na ograniczenia badań empirycznych uzyskane w ich toku wyniki nie będą służyć do tworzenia uogólnień, praw czy twierdzeń. W takim wypadku nie jest

\footnotetext{
${ }^{1}$ Zob. https://od-grosika-do-zlotowki.junior.org.pl/pl

${ }^{2}$ Zob. http://www.pkobp.pl/media_files/61171a02-81d3-40f7-aba6-2af2751a4af7.pdf
} 
konieczne sformułowanie hipotez roboczych. Wyszczególniono natomiast kilka głównych problemów badawczych, którymi były: definicja przedsiębiorczości używana przez uczniów klas trzecich szkoły podstawowej; opinia respondentów na temat uwarunkowań przedsiębiorczości (jako cechy wrodzonej, bądź nabytej); cechy przedsiębiorcy w opinii uczniów klas trzecich; postrzeganie własnej osoby jako przedsiębiorczej przez uczniów klas trzecich; opinia ankietowanych uczniów o realizowanych inicjatywach dotyczących rozwijania przedsiębiorczości.

Odwołując się do pierwszego problemu badawczego, można zauważyć, że uczniowskie definicje przedsiębiorczości przyjęły formę zwięzłej definicji lub krótkiej listy elementów, które w opinii badanych trzecioklasistów charakteryzują przedsiębiorczość. Respondenci najczęściej definiowali wskazany termin jako działalność polegającą na prowadzeniu firmy (78 wskazań). Takiej odpowiedzi udzieliło 72\% respondentów. Ponad połowa badanych trzecioklasistów (63\%) przedsiębiorczość utożsamiała także z możliwością zarabiania pieniędzy (68 wskazań), a w 60 dziecięcych wypowiedziach podany termin został zdefiniowany jako rządzenie i zarządzanie. 52 wskazania dotyczyły rozumienia przedsiębiorczości jako właściwości pozwalającej na życie w luksusie, natomiast 33 badanych uczniów (31\% respondentów) zwróciło uwagę na fakt, że przedsiębiorczość to cecha pozwalająca radzić sobie w różnych sytuacjach. Uczniowie podtarnowskich szkół sporadycznie wskazywali na takie elementy, jak: pomysłowość (25 wskazań), aktywność (13 wskazań), spryt (10 wskazań), twórczość (9 wskazań), ryzyko (8 wskazań). Tylko dwoje uczniów stwierdziło, że przedsiębiorczość łączy się ze skutecznością. W badanej grupie najrzadziej (po jednym wskazaniu) pojawiały się elementy, takie jak: inwestycja, kredyt. Natomiast 22 uczniów nie udzieliło żadnej odpowiedzi. Definicje terminu „przedsiębiorczość" w ujęciu trzecioklasistów zestawiono na rycinie 1.

Analizując wyniki dotyczące drugiego problemu badawczego, który dotyczył opinii trzecioklasistów na temat uwarunkowań przedsiębiorczości, można zauważyć, że mniej

Rycina 1. Definicje przedsiębiorczości w ujęciu badanych uczniów klas trzecich

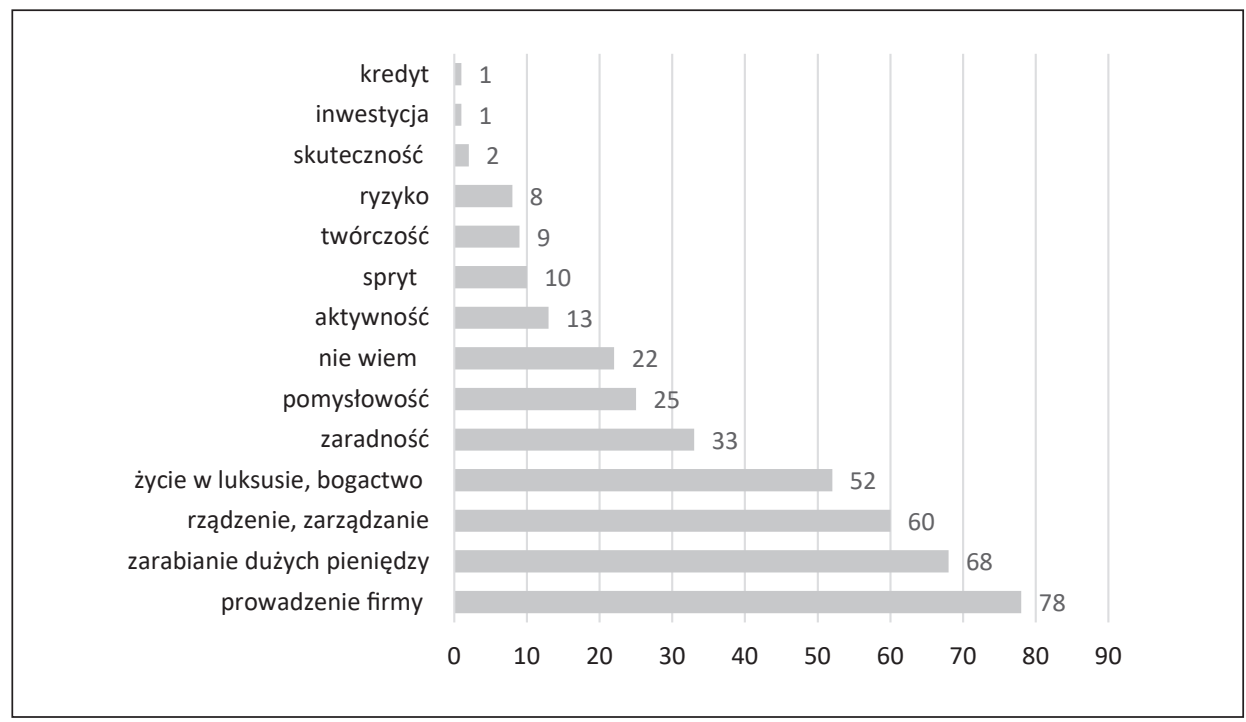

Źródło: badanie własne 
niż połowa badanych uczniów (49\%) na pytanie o to, czy każdy człowiek może być przedsiębiorczy, udzieliła odpowiedzi twierdzącej, 15\% uczniów uważało, że przedsiębiorczość to cecha wrodzona, przynależna tylko niektórym jednostkom, a 36\% respondentów nie miało zdania na ten temat. Odpowiedzi uczniów zaprezentowano na rycinie 2.

Poddając analizie trzeci wątek badawczy, identyfikujący wiedzę respondentów na temat cech i umiejętności osoby przedsiębiorczej, można wskazać cechy najczęściej i najrzadziej typowane przez badanych trzecioklasistów. W opinii dzieci klas trzecich człowiek przedsiębiorczy jest przede wszystkim bogaty (76 wskazań) i sprytny (72 wskazania). Połowa ankietowanych (54 uczniów) wskazała, że wyróżnikiem przedsiębiorcy jest nie cecha jego charakteru lub umiejętność, lecz efekt podejmowanych przez niego działań (firma). Uczniowie klas trzecich często proponowali też jako cechę zaradność (52 wskazania). Rzadziej wymieniane były określenia: pomysłowy (38 wskazań), umie oszczędzać (36 wskazań), dobrze liczy (35wskazań), nic nie robi (31 wskazań), karierowicz (30 wskazań), szczęściarz (27). Tylko niektóre dzieci podkreśliły określenia takie, jak: pewny siebie (25 wskazań), ma wiedzę, ciężko pracuje (po 20 wskazań). Odpowiedzi uczniów zaprezentowano na rycinie 3.

W badaniu próbowano też zebrać opinie uczniów na temat postrzegania siebie jako osoby przedsiębiorczej. Zapytano uczniów o to, czy uważają się za osoby przedsiębiorcze i czy chcieliby w przyszłości zostać przedsiębiorcami. Respondentów poproszono też o uargumentowanie swojej wypowiedzi. W zebranym materiale badawczym $36 \%$ stanowiły odpowiedzi twierdzące. Do najczęściej pojawiających się argumentów należały: „tak, bo można dużo zarobić”, „to daje pieniądze”, „można łatwo zarobić”, „lubię rządzić i wydawać polecenia”. 10\% ankietowanych udzieliło odpowiedzi przeczącej, używając uzasadnień, takich jak „nie warto być przedsiębiorcą, bo firmy upadają”, „nie, bo trudno jest kierować firmą”, „to zajmuje dużo czasu i trudu”. Zdecydowana większość (54\% respondentów) nie miała zdania na ten temat. Plusem bycia przedsiębiorcą jest w opinii

Rycina 2. Opinie respondentów z klas trzecich na temat uwarunkowań przedsiębiorczości

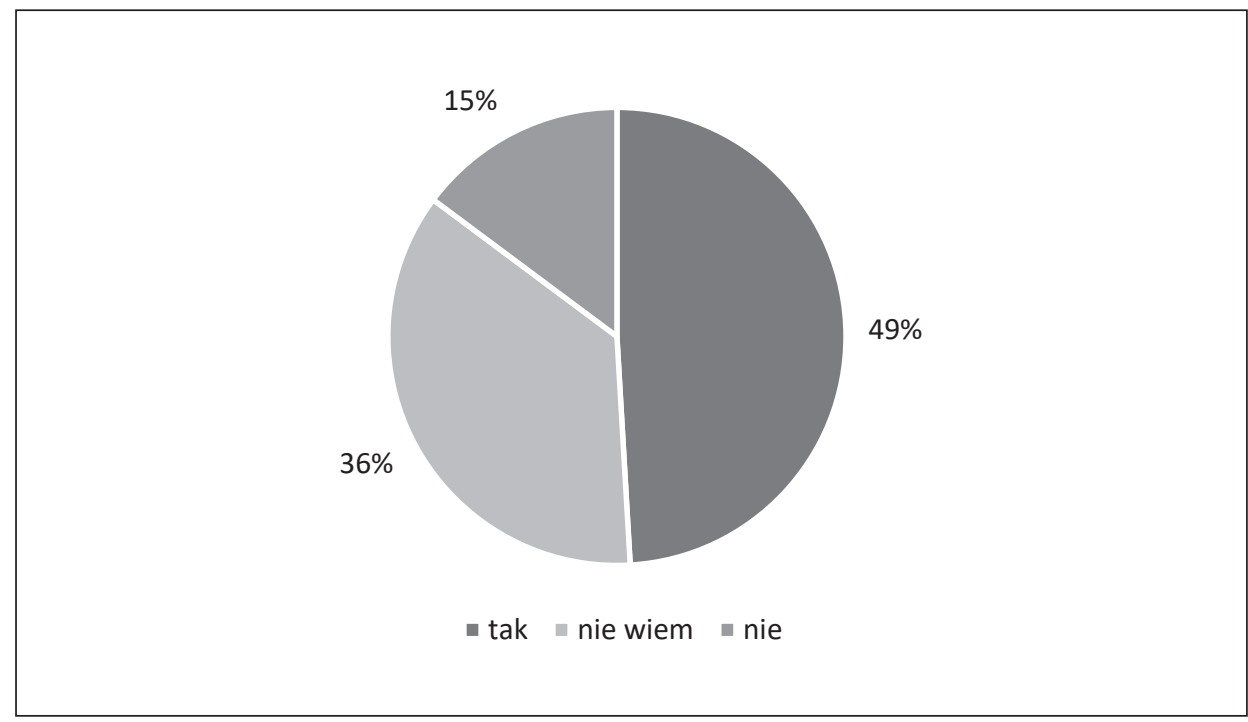

Źródło: opracowanie własne 
Rycina 3. Cechy i umiejętności osoby przedsiębiorczej w opinii badanych uczniów klas trzecich

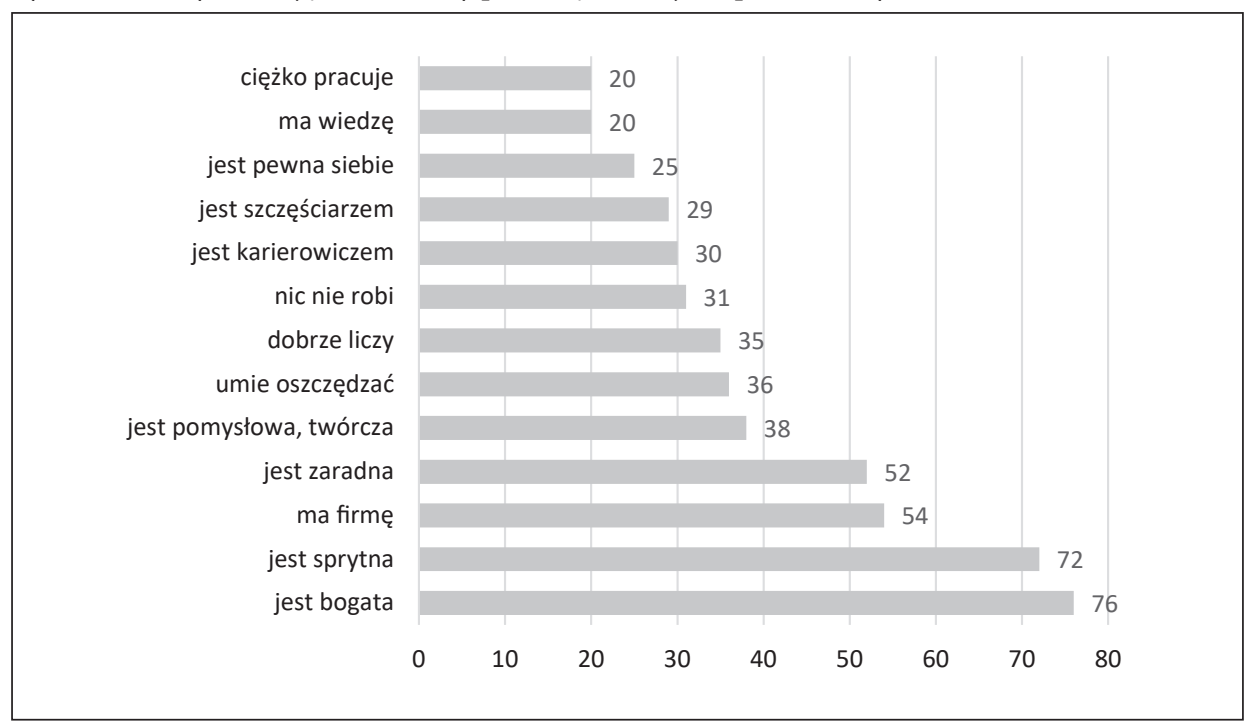

Źródło: opracowanie własne

niektórych uczniów wysokie wynagrodzenie i możliwość kierowania innymi. Nieznaczna część uczniów (16\%) zwróciła uwagę na satysfakcję wynikającą z pomocy niesionej innym dzięki posiadanej kompetencji przedsiębiorczej. Dookreślając problem badawczy, próbowano ustalić, czy i jakie cechy oraz umiejętności charakterystyczne dla postawy przedsiębiorczej dostrzegają u siebie badane dzieci. 96\% uczniów uważało się za osoby potrafiące wyszukiwać informacje, $85 \%$ badanych twierdziło, że zna swoje mocne i słabe strony, $75 \%$ uczniów uważało się za aktywnych, a $72 \%$ - za osoby potrafiące komunikować się z innymi. Do najrzadziej wskazywanych cech należały: wytrwałość (22\%), podejmowanie ryzyka (19\%) i skuteczność (13\%).

$\mathrm{Na}$ koniec respondenci wypowiedzieli się na temat szkolnych przedsiębiorczych inicjatyw. Wszyscy zadeklarowali, że w szkole mieli możliwość wzięcia udziału w akcjach charytatywnych (m.in. Góra Grosza, zbieranie zakrętek, Szlachetna Paczka), jednak tylko 1/3 badanych wskazała, że była zaangażowana w zorganizowanie takiej działalności. $75 \%$ uczniów brało udział w spotkaniach z przedstawicielami różnych zawodów, ale tylko $15 \%$ podkreśliło, że były to spotkania z przedsiębiorcami, osobami prowadzącymi firmę. Tylko 20\% uczniów uczestniczyło w ciągu trzech lat edukacji w wydarzeniach naukowych, np. w Festiwalach Nauki.

\section{Wnioski}

Badani uczniowie klas trzecich posiadali fragmentaryczną wiedzę na temat przedsiębiorczości i nie potrafili sformułować pełnej, poprawnej definicji dla tego terminu, co wskazuje na to, że prezentowali potoczne rozumienie wskazanego pojęcia. Wypowiedzi respondentów na temat przedsiębiorczości odbiegały od definicji literaturowych i nie uwzględniały określeń takich jak: „postawa”, „proces”, „zachowanie”, pojawiających się w dokumentach podkreślających istotne znaczenie przedsiębiorczości w szkole. Respondenci 
pomijali ważne dla postawy przedsiębiorczej aspekty, m.in.: wyobraźnię, umiejętność: planowania, analizowania, krytycznego i strategicznego myślenia, wytrwałość, pasję. Uczniowskie definicje przedsiębiorczości często odnosiły się do jej ekonomicznej i biznesowej strony skierowanej na wartości hedonistyczne (konsumpcjonizm), zapewniające dobrobyt i luksus. Na podstawie analizy zebranego materiału można przypuszczać, że w badanych szkołach nie tworzy się uczniom zbyt często okazji do praktycznych ćwiczeń w zakresie definiowania pojęć związanych z omawianą kompetencją kluczową.

Mimo że prawie połowa badanych uczniów ma świadomość, iż przedsiębiorczość to właściwość, do której można dążyć i którą można rozwijać, to tylko niektórzy znają metody i strategie pomocne w nabywaniu umiejętności przedsiębiorczych. Duża liczba odpowiedzi sugerujących brak wyrobionego zdania na ten temat oraz odpowiedzi negatywne opatrzone komentarzem takim jak: „nie każdy może być przedsiębiorcą, bo do tego trzeba mieć talent”, mogą wskazywać, że nie wszyscy uczestnicy badania wiedzą, jakie czynności należy podejmować, by stać się osobą przedsiębiorczą, lub mają takie zdanie ze względu na własne osobiste doświadczenia, budowane na podstawie opinii np. zasłyszanych od dorosłych.

Nie napawa optymizmem wyłaniający się z badań wniosek, że wielu badanych trzecioklasistów kojarzy przedsiębiorcę wyłącznie z osobą zamożną, posiadającą firmę, a więc odnosi się jedynie do aspektu ekonomicznego przedsiębiorczości, pomijając inne kompetencje, w tym: wytrwałość, odpowiedzialność, umiejętność przewidywania, analizowania, chęć zdobywania wiedzy, stawianie sobie wyzwań. Prawie 1/3 uczniów uważała, że typowymi cechami osoby przedsiębiorczej są umiejętności matematyczne (liczenia), a jednocześnie pomijała równie ważne, gdyż odnoszące się do kwestii etycznych cechy przedsiębiorcy, takie jak: empatyczność, uczciwość, odpowiedzialność. Prawdopodobnie oznacza to, że realizacja zagadnień zawartych w podstawie programowej dla pierwszego etapu kształcenia w badanych szkołach oscyluje głównie wokół umiejętności typowo szkolnych - liczenia i pisania, przy jednoczesnym pominięciu innych ważnych wartości uniwersalnych, których przejawami są np. uczciwość czy empatia.

Niewielu badanych uczniów widziało siebie w roli przyszłego przedsiębiorcy. Dzieci nie dostrzegały u siebie ważnych cech i umiejętności, takich jak umiejętność kierowanie zespołem, wytrwałość, cierpliwość. Na tej podstawie można wnioskować, że badani uczniowie szybko poddają się w obliczu wyzwań i trudności, obawiając się ryzyka i ponoszenia odpowiedzialności. Można też przypuszczać, że słabo radzą sobie w sytuacjach niezaplanowanych, wymagających podejmowania wysiłku i ryzyka.

Z uzyskanych wyników można wysnuć wniosek, że w szkołach, do których uczęszczają badani respondenci, pojawiają się sytuacje sprzyjające rozwijaniu przedsiębiorczych postaw, ale organizowane są one przez uczniów klas starszych z pominięciem inicjatywy dzieci klas młodszych, co nie stawi dobrego prognostyku w planowaniu i osiąganiu sukcesów.

Reasumując, można stwierdzić, że pomimo wytycznych ujętych w dokumentach (zarówno europejskich, jak i wewnątrzkrajowych) wyznaczających priorytety w zakresie edukacji przedsiębiorczej, treści z tego obszaru są sporadycznie i wąsko akcentowane przez nauczycieli pracujących z ankietowanymi uczniami. Należałoby zatem zintensyfikować szkolne działania mające na celu nie tylko wyposażenie uczniów w wiadomości na temat przedsiębiorczości, lecz przede wszystkim w umiejętności, dzięki którym będzie można przypisać im cechy osoby przedsiębiorczej. By to osiągnąć, warto wskazane w opracowaniu dobre praktyki stosować nie okazjonalnie, lecz systematycznie, tak by 
widniejące w regulacjach prawnych zapisy dotyczące kształtowania postaw przedsiębiorczych uczniów klas I-III miały przełożenie w praktyce szkolnej.

\section{Literatura}

\section{References}

Andrzejczyk, A. (2016). Wplyw edukacji a rozwój przedsiębiorczości. Raport z badań. Białystok: Polskie Towarzystwo Ekonomiczne.

Brzezińska, A. Schmidt, J. (2008). Przedsiębiorczość jako warunek udanego startu w dorosłość. W: A. Andrzejczak (red.), Przedsiębiorczość w edukacji. Poznań: Wydawnictwo Akademii Ekonomicznej, 21-23.

Fundacja Młodzieżowej Przedsiębiorczości. (2020, 15 marca). Program: Od grosika do złotówki. Pozyskano z: https://od-grosika-do-zlotowki.junior.org.pl/pl

Gołębiowski, G. (2014). Analiza finansowa przedsiębiorstwa. Warszawa: Difin.

Holmgren, C., From, J. (2005). Taylorism of the Mind: Entrepreneurship Education from a Perspective of Educational Research. European Educational Research Journal, 4(4), 382-390.

Kapica, G. (2015). Modernizacja organizacji procesu kształcenia młodszych uczniów. W: E. Smak, K. Wereszczyńska, A. Malec (red.), Wspótczesne trendy w edukacji. Opole: Wydawnictwo Uniwersytetu Opolskiego, 75-81.

Majkut, R. (2014). Przedsiębiorczość w świetle uwarunkowań interdyscyplinarnych. Warszawa: Wydawnictwo CeDeWu.

Piecuch, T. (2013). Przedsiębiorczość. Podstawy teoretyczne. Warszawa: Wydawnictwo C.H. Beck.

PKO Bank Polski. (2020, 15 marca). Komplet scenariuszy lekcji o finansach dla nauczycieli kl. I-III. Pozyskano z: http://www.pkobp.pl/media_files/61171a02-81d3-40f7-aba6-2af2751a4af7.pdf

Rachwał, T. (2019). Kształtowanie kompetencji przedsiębiorczych. W: T. Rachwał(red.), Przedsiębiorczość jako kompetencja kluczowa w systemie edukacji. Warszawa: Wydawnictwo FRSE, 16-35.

Roudaki, J. (2009). University Students Perceptions on Entrepreneuruschip: Cmmerce Students Attitudes ad Lincoln University. Journal of Accouting - Business and Management, 16(2), 36-53.

Rozporzadzenie Ministra Edukacji Narodowej z dnia 14 lutego 2017 r. w sprawie podstawy programowej wychowania przedszkolnego oraz podstawy programowej kształcenia ogólnego dla szkoły podstawowej, $w$ tym dla uczniów z niepetnosprawnościa intelektualnq $w$ stopniu umiarkowanym lub znacznym, kształcenia ogólnego dla branżowej szkoły I stopnia, kształcenia ogólnego dla szkoły specjalnej przysposabiajacej do pracy oraz kształcenia ogólnego dla szkoły policealnej. Dz.U. 2017, poz. 356.

Sadowska, M. (2016). Edukacja w zakresie przedsiębiorczości w polskim systemie kształcenia oraz w państwach europejskich. Przedsiębiorczość Międzynarodowa, 2(1), 149-164.

Ustawa $z$ dnia 14 grudnia 2016 r. Prawo Oświatowe. Dz.U. 2019, poz. 1148 ze zm.

Uygun, R., Kasimoglu, M. (2013). The Emergence of Entreneurial Intentions in Indigenous Entrepreneurs: The Rolle of Personal Backgrount on the Antecedents of Intentions. International Journal of Business and Management, 8(5), 24-40.

Wach, K. (2013). Edukacja na rzecz przedsiębiorczości wobec współczesnych wyzwań cywilizacyjno-gospodarczych. Przedsiębiorczość - Edukacja [Entrepreneurship - Education], 9, 246-257.

Zalecenie Parlamentu Europejskiego i Rady z dnia 18 grudnia 2006 r. w sprawie kompetencji kluczowych $w$ procesie uczenia się przez całe życie (2006/962/WE).

Zalecenie Rady z dnia 22 maja 2018 r. w sprawie kompetencji kluczowych w procesie uczenia się przez całe życie (Tekst mający znaczenie dla EOG), Dz.Urz. UE 2018/C 189/01.

Maria Janas, mgr, doktorantka, Uniwersytet Pedagogiczny im. Komisji Edukacji Narodowej w Krakowie, Wydział Nauk Społecznych, Instytut Pedagogiki Przedszkolnej i Szkolnej, Katedra Pedagogiki Wczesnoszkolnej. Jej zainteresowania naukowe i badawcze skoncentrowane są wokół 
problematyki kreatywności, strategii rozwijania inicjatywności, przedsiębiorczości i aktywności twórczej uczniów edukacji wczesnoszkolnej.

Maria Janas, MA, a PhD student, Pedagogical University of Krakow, Faculty of Social Sciences, Institute of Pre-school and School Pedagogy, Department of Early Childhood Pedagogy. Her academic and research interests are focused around the issues of creativity, strategies for developing initiative, entrepreneurship and creative activity of early childhood education students.

ORCID: https://orcid.org/0000-0002-3483-9408

\section{Adres/Address:}

Uniwersytet Pedagogiczny im. Komisji Edukacji Narodowej w Krakowie Instytut Pedagogiki Przedszkolnej i Szkolnej

Katedra Pedagogiki Wczesnoszkolnej

ul. Podchorążych 2

30-084 Kraków, Poland

e-mail: maria.janas@up.krakow.pl 